\title{
Can Fiscal Responsibility Legislation be Made to Work?
}

\author{
Marc Robinson
}

F

ISCAL responsibility is about ensuring that fiscal decisions are not dominated by present considerations at the expense of future ones. It means recognising that decisions that directly impact upon the future - borrowing, assetcreation, and arrangements, like government guarantees, which create contingent liabilities - should be guided by relevant medium- and long-term objectives such as inter-generational equity and the avoidance of excessive financial risk.

There is no shortage of examples of fiscal irresponsibility in democratic countries where parliamentary scrutiny, voter common sense, and financial market disciplines appear to have failed: whether on a spectacular scale (as in the Brazilian State of Sao Paulo), on an intermediate scale (Belgium), or on a lesser but nevertheless serious scale (Victoria until the early 1990s). The notion that governments should be constrained to be fiscally responsible, therefore, has much appeal. In the United States, for example, the failure of political institutions over more than a decade to solve an almost universally acknowledged budget deficit problem has led to a number of attempts to legislate for a solution, such as the Gramm-Rudman Act of 1985. More recently, the Congressional Republicans only very narrowly failed to pass legislation setting in train a process to amend the US constitution so as to require balanced budgets.

Yet the idea of legislating to compel fiscal responsibility is not new. Constitutional or statutory balanced budget requirements and debt limits have existed for a long time in many countries. In the 19th century, the Australian colonies effected legislative debt limits and requirements for 'consolidated account' balanced budgets. Some of these provisions still exist in certain States. Over the last two years, the idea of legislating for fiscal responsibility has gained considerable currency in Australia. The former Coalition government of New South Wales in late 1994 attempted, and only narrowly failed, to secure legislation amending the State Constitution so as to require balanced budgets. A year later, its Labor successor passed legislation purporting to commit itself and future governments to medium- and long-term fiscal responsibility targets, the foremost of these being the 'elimination' of the budget sector's net debt. At the federal level, the Business Council of Australia (BCA, 1995:2) in September 1995 called for legislation 'requiring a surplus Budget on average over the business cycle'. It reiterated this theme during the 1996 
federal election campaign (BCA, 1996), at which time Dr Vince FitzGerald (1996:15) similarly appealed for a 'legislated commitment to fund fully current spending out of current revenues, on average over the cycle, and to finance some public investment out of current surpluses, that is, savings'.

\section{Constraints, Declarations and Reports}

Significantly, a great diversity exists among the fiscal rules and targets that have been proposed or implemented around the world. There are expenditure limits, balanced-budget requirements (whether specified in terms of the overall cash balance, the cash current-account balance, the accrual operating balance, the traditional 'consolidated account' balance or some other concept), targets for the reduction or elimination of debt, debt ceilings (variously formulated), a variety of debt amortisation rules, and net worth targets. The failure of even relatively informed opinion to agree upon a single appropriate target or set of complementary targets highlights a key problem for advocates of fiscal-responsibility legislation. Legitimate differences of opinion - reflecting differences of both philosophic and theoretical outlook exist as to the appropriate medium- and long-term fiscal rules. So even if compulsory fiscal responsibility legislation worked, it would inevitably amount to the codification of one particular and controversial conception of fiscal responsibility.

Yet experience clearly indicates that attempts to compel fiscal responsibility through legislation do not work. Such legislation is susceptible to evasion, and is prone to induce perverse consequences. Von Hagen's (1991:209) conclusion on the experience of American States, almost all of which have some such legislation, is representative (see also, for example, Heins, 1963):

... despite their impact on fiscal policies, fiscal restraints do little to reduce the likelihood of extreme outcomes in fiscal performance. The most significant effect of fiscal restraints is to induce governments to substitute nonrestricted for restricted debt instruments, thereby reducing the relevance and informativeness of data on government debt.

A spectacular US example of this failure is the debt default of New York City in 1974, notwithstanding a constitutional balanced budget requirement (Suits \& Fisher, 1985:474-6). Bennet and DiLorenzo (1983:175) summarised clearly the lessons and implications of the US experience with mandatory fiscal constraints in a wellknown study prepared for the Cato Institute:

History has shown that statutory and constitutional limits on debt can be, and on a large scale have been, evaded by politicians at the state and local levels. Those frustrated taxpayers who expect a balanced budget amendment to the Constitution to work miracles in controlling federal spending are, if the past is any guide, likely to be very disappointed. 
Past failures reflect these intrinsic difficulties rather than simply defects in the formulations used. This implies that the presence of weaknesses in the political system which may at times encourage fiscal irresponsibility is irrelevant to the issue at hand. Arguably, the extent of these flaws has been exaggerated by many advocates of compulsory fiscal responsibility. (The punishment meted out by the Victorian electorate to its Labor government, and the willingness of the same electorate to swallow bitter fiscal medicine from the Coalition government that followed it in late 1992, is one recent demonstration that in this country serious fiscal irresponsibility has a high electoral price.) Ultimately, however, it does not much matter how much faith one does or does not have in the effectiveness of political mechanisms, reinforced by market disciplines, if one recognises that, however superficially attractive, the idea of constraining governments to be fiscally responsible simply cannot withstand close examination.

The fact that legislation cannot compel fiscal responsibility does not, of course, mean that legislation may not play an important role in encouraging fiscal responsibility. There is already a considerable body of financial reporting and related legislation which has precisely that effect. Legislative fiscal-responsibility constraints are not, therefore, to be equated either with fiscal responsibility declarations or with fiscal reporting legislation. Fiscal responsibility declarations are discretionary commitments undertaken by executive governments to fiscal responsibility rules and targets. Fiscal reporting legislation, by contrast, requires the reporting of specified fiscal measures, or the more explicit delineation of fiscal policy, but does not nominate fiscal rules or targets. Legislation which seeks to compel fiscal responsibility must of necessity include or rely upon mandatory reporting requirements in respect of the relevant fiscal targets. It requires, but is distinct from, fiscal reporting legislation. It is argued below that the legislative Charter of Budget Honesty developed by Australia's Howard Government is best viewed as fiscal reporting legislation in this sense, notwithstanding the superficial impression created by the 'principles of sound fiscal management' which it articulates.

For it to be possible to use legislation to coerce reluctant or recalcitrant governments into behaving in a fiscally responsible manner, it must be feasible and cost-effective to define fiscal targets which:

- are clearly and unambiguously specified;

- are, or can be made, susceptible to ready verification by analysts outside government; and

- give effect to fiscal responsibility principles, and do so without unacceptably trading off good policy in other areas. (It should not be possible to comply with the letter of the law in a manner which runs contrary to its spirit.)

There are two fundamental reasons why it is not possible to formulate fiscal responsibility legislation which can meet these criteria. The first is the impossibility 
of dealing satisfactorily with uncertainty. The second is an acute and unresolvable performance measurement problem.

\section{Uncertainty}

Dealing with the impact upon the government's financial position of financial shocks and uncertainty in key economic parameters presents an enormous problem for fiscal responsibility legislation. Many - perhaps most - economists believe that short-run fiscal settings need to take into account macroeconomic and other contextual variables. But it is impossible to specify in advance the range of contingencies which may impact upon the budget. As well, the appropriate fiscal rules and targets vary with each of the possible contingencies. One is, therefore, forced to choose between, on the one hand, tightly specified fiscal targets which by their very nature will produce damaging inflexibility under some circumstances and, on the other hand, loosely specified fiscal targets which may permit appropriate flexibility in the face of shocks, but which will give irresponsible governments much greater scope to circumvent the intention of the legislation.

The most familiar example of this problem is the failure of such legislation to deal satisfactorily with the budgetary impact of the business cycle. The concept of a 'cyclically-adjusted' deficit may appear straightforward, but in reality there are very considerable measurement problems, even with ex post measures (Blejer \& Cheasty, 1991:1654-5). Attempting to use an $c_{X}$ ante measure as the basis for a concrete fiscal target would add to this an enormous uncertainty problem. The problem of dealing with the business cycle arises even if one does not favour 'activist' fiscal policy, but merely takes the view that pro-cyclical fiscal behaviour is highly undesirable. Bayoumi and Eichengreen (1995:46) suggest that in the US state fiscal constraints have produced a 'reduction in national fiscal stabilisers . . . [which] could lead to a noticeable increase in the variance of national output'.

The problem of uncertainty is, however, a much wider one. Examples of fiscal shocks which give rise to precisely the same type of difficulties for the formulation of fiscal targets include:

- financial shocks from the public trading enterprise and public financial enterprise sectors. A recent devastating example of this was the impact of the huge losses of the State Bank of South Australia upon that State's budget;

- unanticipated Commonwealth grants cuts (in the case of State governments); and

- unanticipated substantial changes in measured net debt arising from valuation effects (it is standard practice for Australian governments to use 'market' valuations rather than face value in valuing financial assets and liabilities). Changes in interest rates and exchange rates (for foreign-denominated debt) can and do result in considerable volatility in valuations. 
The problem of uncertainty is in no way mitigated by accounting reform. Indeed, accrual accounting exacerbates the problem, by broadening the categories of assets and liabilities subject to valuation shocks and adjustments, with consequent impact upon the operating balance. Further, some of these shocks will be brought to account far more rapidly under accrual accounting than under traditional accounting, so increasing the dislocation likely to be caused by the enforcement of a fiscal target which was not formulated with full foresight. In the South Australian example referred to above, cash accounting had the effect of spreading the shock resulting from the call on the government's guarantee of the liabilities of the State Bank of South Australia over approximately three years.

Some commentators, nevertheless, believe that the benefits to be derived from sticking to pre-specified long-term fiscal rules irrespective of circumstances exceed the costs of fiscal inflexibility. They tend to be economists who believe that fiscal settings have relatively little impact upon real macroeconomic variables. Does this mean that one's view on the appropriateness of legislation to compel fiscal responsibility is essentially a function of the macro-theoretical framework one uses to make sense of the world? The answer to this question is 'no', because measurement problems make compulsory fiscal responsibility impracticable regardless of how desirable it might or might not be.

\section{The Measurement Problem}

It would be a serious mistake to assume that there is, or could ever be, a set of accounting measures capable of giving precise, unambiguous and readily verifiable expression to given fiscal responsibility principles. Accounting measures are, by their very nature, imprecise and ambiguous. And even if they were not, their usefulness would inevitably be undermined by the availability of substitute transactions capable of achieving broadly the same effect as a 'regulated' transaction while falling outside the scope of the fiscal responsibility legislation.

Even at the theoretical level, there is no unique set of accounting measures that is both free of conceptual ambiguities and generally acknowledged to be superior to all others. There is an inherent ambiguity in imposing upon an essentially continuous set of transactional attributes a discrete classification framework. And however precise accounting concepts may be at the theoretical level, high information costs mean that, more often than not, conceptual purity has to be compromised in practice. An important consequence of all this is that all real-world accounting systems both permit a choice of alternative measures for important types of transaction, and rely greatly upon judgment and discretion in their practical implementation.

When one adds to this a recognition of the great multitude of micro-decisions about the classification of transactions which generate the accounting aggregates in terms of which fiscal targets and rules are expressed, it becomes clear that external monitoring is no easy or straightforward task. There are numerous examples of governments perpetrating accounting manipulations and either escaping detection by Auditors-General, or, if caught, resorting to arcane debate on accounting technicalities in order to cloud the issue. 
Two illustrations demonstrate the point. The first concerns the vital distinction between current and capital expenditure. 'Adjusting' the allocation of expenditure between the two categories is one of the most enduring types of accounting fiddle. As one US federal Budget Director observed, 'once you have a capital budget, it would be the propensity of politicians to load everything onto the books and borrow against it' (Khalaf, 1991:74). In Victoria, the Cain-Kirner Labor government of 1982-92 was accused of classifying current expenditure as capital in order to reduce the apparent budgetary current account deficit. Its successor, the Kennett Coalition government, was then accused of precisely the opposite crime: of 'sandbagging' the apparent current account surplus by classifying capital expenditures as current in order to prolong politically useful public anxiety about the State's financial position.

Even at the theoretical level, the capital-current distinction is not straightforward. A substantial body of opinion, for example, holds that much expenditure in areas such as health and education should be classified as capital because it produces a stream of benefits into the future (see Depta, Ravalli \& Harding, 1994). Others reject the view that such expenditures should be treated like other capital expenditure, either on practical, and sometimes on theoretical, grounds (see National Commission of Audit, 1996:xvi, 146). Notwithstanding this, most informed economic opinion recognises that it is profoundly misguided to specify fiscal targets without taking into account the capital-current distinction.

A second illustration of the measurement problem concerns transactions between different sectors of government. The standard way in which Australian Commonwealth governments achieve 'fiscal responsibility' is by imposing most expenditure cuts upon the States. With the great bulk of States' grants classified as a current expenditure, such cuts produce an equivalent 'improvement' in the federal budget current account. However, a standard response of the States, particularly in the short run, has been to cut capital expenditure, because it is an area with greater flexibility. There is no solution to the conundrum which this poses for someone charged with the task of drafting fiscal responsibility legislation. At the heart of this conundrum is the inherent ambiguity of classifying grant expenditures as capital or current in the accounts of the grantor when the capital or current nature of the expenditure concerned depends upon decisions of the recipient: decisions which are neither controllable nor predictable (nor even readily measurable, given that it is not meaningful to distinguish one dollar of State revenue from another).

Similar issues arise in relation to transactions between the 'budget sector' and 'public trading enterprise sector' within each level of government. Although a currently fashionable solution to this might appear to be accounting consolidation into a so-called 'whole of government' framework, this not only raises problems of control analogous to those arising in relation to States grants (particularly in the context of the current support for much expanded autonomy for public enterprises), but also creates serious difficulties for the appropriate specification of fiscal targets which need to be appropriate for an entity comprised of two sectors with great differences in fundamental objectives and operating environment. 
The introduction of accrual accounting has frequently been represented as a means of eliminating, or at least greatly reducing, the scope for accounting manipulation (Churchill, 1992:18; Mellor, 1996:80). This may reflect the fact that accrual accounting does forestall certain of the more obvious methods of creative accounting under the cash accounting system, such as arrangements designed to artificially change the timing of recorded cash flows. However, the advent of accrual accounting will not compel government accountants to take up violin playing and French clock appreciation to provide an outlet for their renowned creative urges. As Redburn notes, 'with a shift to an accrual framework, some uncertainties are added and others are removed'. One area which provides 'plenty of opportunity to play games' in an accrual environment is valuation based upon cash-flow estimation (Redburn, 1993:233), of the type which is required in accounting for superannuation liabilities, workers' compensation liabilities and perhaps even social security liabilities. The issues that arise in distinguishing capital from current expenditure remain just as relevant in accrual accounting, and are joined by issues concerning depreciation methodology and depreciation schedules. There are, moreover, important conceptual issues such as the appropriate valuation methodology for infrastructure assets (Robinson, 1996). As one leading Australian accounting academic has noted, the '[accrual] accounting methods being adopted within the public sector are so flexible (and amenable to manipulation) that often, little credence may be placed on many of the numbers presented in published accrual-accounting based reports' (Walker, 1995:S 156).

In any event, the record makes clear that even watertight accounting measures would not make fiscal responsibility constraints workable. The availability of unregulated substitutes for regulated transactions seems to know no limits. The classic example of this is debt. In the US, debt limits led to a proliferation of substitutes including sale and leaseback, tax anticipation bonds, manipulation of short-term borrowing entitlements, off-budget borrowing, loan guarantees and a host of others (Goldner, 1991:936; Bennett \& DiLorenzo, 1983; Heins, 1963). But Australians hardly need to look abroad for examples of such ingenuity. The same lesson is clearly demonstrated by the cat-and-mouse game played by the States over the past 20 or more years as they sought to evade Commonwealth controls on their borrowing, and, more recently, to delude their own electorates as to the extent of financial liabilities they were leaving to the future. Operating leases and similar arrangements have in recent times been replaced with the far more 'innovative' approach of persuading the private sector to either purchase or create de novo public infrastructure. Under this system, what would otherwise have been a government interest liability is replaced by continuing commitments in the form either of a service contract with government or a legislatively conferred right to levy monopoly charges directly upon the public. The Port Macquarie Hospital in NSW, and the Citylink project in Victoria, are cases in point.

In Australia, as in the US (Bayoumi \& Eichengreen, 1994; Heins, 1963:vii), a serious by-product of this game of fiscal illusion is a quite unnecessary increase in the effective cost of funds relative to straightforward public borrowing. Private 
provision of public infrastructure is merely the most recent example of this (EPAC, 1995). While this is to be encouraged when cost-effective, Australia is experiencing an epidemic of private infrastructure projects that are demonstrably more costly than traditional public provision, motivated primarily by a desire to window-dress debt statistics. Both the examples cited above (the Port Macquarie Hospital and the Citylink project) fall into that category (NSW Auditor-General, 1996; Australian Financial Revew 15 December 1995, Age, 7 June 1996). The NSW government, for example, publicly indicated that it had been its intention to rely upon the privatisation of public infrastructure to enable it to meet the objectives of its debtelimination legislation (Sydney Morning Herald, 18 December 1995).

The difficulties confronting attempts to formulate legislatively binding fiscal constraints are an example of the general problem of the inappropriateness of 'classical' contracting to many types of transaction. Classical contracting seeks, in essence, to define in advance unambiguous performance standards by clearly specifying the manner in which relevant future contingencies might modify the definition of adequate performance. Williamson (1985:68-84) makes the point that uncertainty and substantial performance measurement difficulties often makes this type of contracting inefficient and impractical.

\section{Judicial Enforcement}

This leads naturally to the issue of enforcement and sanctions. For legislation to constrain an unwilling or opportunistic government, there must be an effective enforcement mechanism.

As with other legislation, the courts could adopt either a 'black letter law' approach of literal interpretation towards fiscal responsibility legislation or, alternatively, a more interpretive approach designed to give effect to the spirit, rather than the literal wording, of the law. The impossibility of dealing satisfactorily in the formulation of this legislation with the measurement difficulties and uncertainty problems discussed above means that each of these approaches would be thoroughly unsatisfactory. Literal interpretation would result in a combination of damaging inflexibility and inability to deal with even the simplest avoidance strategies. This is borne out clearly by the US experience, where 'narrow interpretation . . . by the courts' has 'undermined the usefulness of debt limitations' while simultaneously ensuring that choices of quasi-debt instruments are driven by legal considerations rather than policy rationality (Goldner, 1991:935-8). Meanwhile, judges attempting to overcome this problem by interpreting the 'spirit' of fiscal responsibility legislation would inevitably end up exercising great discretionary power, with much depending upon their philosophic perspectives and even upon their prejudices.

These problems with judicial enforcement perhaps explain the striking absence of sanctions or enforcement mechanisms of any kind in some recent fiscal responsibility legislation. For example, Section 27 of the NSW debt elimination legislation expressly excludes recourse to the courts to enforce its provisions. Legislation of this type may be seen as declaratory at best. Arguably, giving a more symbolic formal status to a fiscal responsibility declaration in this manner could potentially in- 
crease its impact. A more realistic view is that it simply represents an attempt to delude the electorate as to the status of the fiscal constraint.

\section{New Zealand's Fiscal Responsibility Act}

Recent debate on fiscal responsibility legislation in Australia, leading up to the Charter of Budget Honesty, has been greatly influenced by the New Zealand Fiscal Responsibility Act 1994. It is therefore useful to consider the New Zealand legislation in the light of the the preceding analysis, before turning to an analysis of the Charter itself.

The influence upon the Australian debate of the New Zealand Fiscal Responsibility Act is not inappropriate, for the New Zealand Act contains a number of strong points and worthwhile innovations. These lie particularly in the fiscal reporting provisions of the Act, which enhance the transparency of fiscal policy. Not only does the Act require the provision to the public of important additional information on fiscal outcomes, but there is an innovative requirement for the provision of medium- and long-term fiscal projections at specified intervals including in the run-up to general elections. These projections must, by law, be certified by the head of Treasury, significantly reducing the likelihood of political manipulation.

The crucial question, however, is whether the New Zealand legislation aims to compel future governments to be fiscally responsible. On the surface, it appears to do so. Section 4 of the Act states that 'the Government shall pursue its policy objectives in accordance with' certain 'principles of responsible fiscal management', which are specified. It stipulates that departures from these may be only temporary, and must be fully explained. However, closer analysis reveals that there is no attempt in the Act to specify the principles of responsible fiscal management so tightly as to eliminate the scope for avoidance and evasion. For example, one of the five principles laid down (in s.4(2)) refers to 'reducing total Crown debt to prudent levels', while another stipulates 'a reasonable degree of predictability about the level and stability of tax rates'. In addition, no legal sanctions are provided for to deal with a failure to comply with these principles - leaving public opinion as the only effective sanction.

The explananation of this ambivalence is to be found in the conflicting views within the policy community which shaped the legislation. Ruth Richardson, who as Finance Minister originated the legislation and then as Chair of a key parliamentary committee presided over parliamentary examination and re-drafting, was a strong exponent of legislatively binding fiscal rules and targets. Others - and in particular Treasury - disagreed (Kelsey, 1995:232-8). Representative of the latter school of thought is the view subsequently articulated by Graham Scott, Secretary to the New Zealand Treasury at the time the Act was adopted, that "embodying [fiscal rules and targets] in law might not by itself make much difference, particularly if the government of the day is not committed to the goals of the Act'. In a spirit of realism, Scott claims only that 'on the assumption that a future government, particularly its finance minister, is not determined to evade it, the Act can make a significant contribution' (Scott, 1995:9-10). The New Zealand Business Roundtable (1994) takes a 
similar view. It is probably realistic, therefore, to view the New Zealand Act as declaratory rather than constraining. Moreover, the New Zealand parliament is unicameral, so that the fiscal principles of the Act may be viewed as discretionary policy for an executive government with firm control of its parliamentary majority.

\section{The Charter of Budget Honesty}

Much influenced by the New Zealand legislation, the Liberal-National Coalition in Australia announced in July 1995 (Howard, 1995:15) that if elected to office, it would legislatively effect a 'Charter of Budget Honesty'. After coming to office in March 1996, the Coalition obtained advice on the content of the Charter from its National Commission of Audit (National Commission of Audit, 1996:273-300), and then issued a Statement in conjunction with the 1996 budget outlining in detail the form the legislation would take (Costello, 1996).

The 'principles of sound fiscal management' which are the flagship of the Charter of Budget Honesty are more elastic even than those of the New Zealand legislation. They refer to 'prudent' debt levels, a 'reasonable' degree of tax stability and predictability, 'integrity' in the tax system, and assert that policy decisions should 'have regard' to national savings and intergenerational impacts. Moreover, these broad principles will not be accompanied by concrete benchmarks or targets for key fiscal variables, even though in Opposition the Coalition promised that the 'Charter . . . will . . . establish benchmarks against which fiscal policies can be assessed' (Howard, 1995:15).

This makes it clear that, notwithstanding the government's claims that the Charter will 'ensur(e) that fiscal policy is formulated in accordance with principles of sound fiscal management' (Costello, 1996:2), the Charter cannot be regarded as an attempt to compel fiscal responsibility. The 'principles' it lays down are best regarded not as the centrepiece of the Charter, but rather as a vestigial reminder of what the government had hoped to achieve through the Charter before being brought down to earth by advice from Treasury (see Treasury, 1995) and, to a lesser extent, the Commission of Audit. The Charter is therefore best evaluated in terms of its contribution to improving information about the fiscal position and fiscal policy. In that respect, it makes a useful if somewhat disappointing contribution.

The Charter will require pre-election fiscal-outlook statements certified by key officials: a highly desirable step. It will also mandate the provision of three-year fiscal forecasts in proposed Economic and Fiscal Outlook documents. These financial reporting provisions are to be accompanied by 'requirements' that the government make clear its long-term objectives, broad strategic priorities, short-term fiscal objectives and expected outcomes or targets, and so on. In practice, it would be impossible to enforce meaningful compliance with these latter 'requirements' on the part of an obdurately irresponsible government. Nevertheless, the provisions can be expected to create useful additional pressure for policy transparency, without the disadvantages of legislative rules.

A disappointing aspect of the Charter, at least as foreshadowed in the Statement, is the absence of any requirements for information on the long-term fiscal 
position in the form of forecasts or scenarios. The requirement for the publication of three-year forward estimates does little more than formalise what has been the practice for some years. By contrast, the New Zealand legislation requires ten-year forecasts. The Charter is to include a requirement for the provision at five-year intervals of an 'intergenerational report' which could potentially become a vehicle for such information, but the government Statement gives only the sketchiest indication of what this 'report' will contain.

Equally disappointing is the is the failure to recognise the intergovernmental aspects of fiscal responsibility in a federal system. Stability and predictability in Commonwealth grants to the States is just as important as stability and predictability in Commonwealth taxes, particularly given that marked increases in economically inefficient State taxes have been the inevitable consequence of the Commonwealth's approach to federal financial relations. A useful small step towards a recognition of this would have been to extend the fiscal reporting and forecasting undertaken jointly by the Commonwealth and States for the annual National Fiscal Outlook, and to integrate this in the fiscal reporting framework of the proposed Charter.

\section{Promoting Fiscal Responsibility}

It is not possible to compel fiscally responsible behaviour simply by passing laws or constitutional amendments to that effect. There are simply too many potential evasion strategies open to governments, and too many bad policy outcomes associated with those evasion strategies.

This does not mean that legislation should have no role in promoting fiscal responsibility. Legislation ought, however, to be directed towards the enhancement of fiscal transparency and the promotion of independent analysis and debate on fiscal policy, and in particular on medium- and long-run fiscal policy. It should not seek to stipulate and enforce fiscal responsibility principles.

\section{References}

Bayoumi, T. \& B. Eichengreen (1994), "The Political Economy of Fiscal Restrictions: Implications for Europe from the United States', European Economic Review 38 (April): 783-91.

(1995), 'Restraining Yourself: The Implications of Fiscal Rules for Economic Stabilization', IMF Staff Papers 42 (1): 32-48.

Bennett, J. \& T. DiLorenzo (1983), Underground Government: The Off-Budget Public Sector, The Cato Institute, Washington DC.

Blejer, M. \& A. Cheasty (1991), 'The Measurement of Fiscal Deficits: Analytical and Methodological Issues', Journal of Economic Literature 29 (December): 296-303.

Business Council of Australia (BCA) (1995), Submission, in Commonwealth of Australia, Joint Committee of Public Accounts, Inquinies into Fiscal Responsibility and Whole of Government Reporting, Submissions, Vol. 1: S. 142-S. 144.

_ (1996), 'Key Reforms Need to Be Included in Major Party Campaign Launches', Melboume (Media Release, 13 February). 
Churchill, M. (1992), 'The Winds of Change', Australian Accountant, March: 17-20.

Costello, P. (1996), Charter of Budget Honesty, AGPS, Canberra.

Depta, P., F. Ravalli \& D. Harding (1994), Extended Measures of Investment and Saving, The Treasury, Canberra (Treasury Research Paper No. 8).

Economic Planning Advisory Council (EPAC) (1995), Private Infrastructure Task Force Report, AGPS, Canberra.

FitzGerald, V. (1996), 'Fiscal Responsibility Must Be Put before Reform', Australian, 29 January.

Goldner, C. (1991), 'State and Local Government Fiscal Responsibility: an Integrated Approach', Wake Forest Law Review 26: 925-63.

Heins, A. (1963), Constitutional Restrictions Against State Debt, University of Wisconsin Press, Madison.

Howard, J. (1995), A Competitive Australia, Liberal Party of Australia, Canberra.

Kelsey, J. (1995), Economic Fundamentalism: The New Zealand Experiment - A World Model for Structural Adjustment?, Pluto Press, London.

Khalaf, R. (1991), 'Lies, Damned Lies, and the Budget Deficit', Forbes, 9 December.

New Zealand Business Roundtable (1994), Submission to the Finance and Expenditure Committee of the House of Representatives on the Fiscal Responsibility Bill, Wellington (28 February).

NSW Auditor-General (1996), 'Accounting for Private Provision of Public Infrastructure: Water and Health Projects', in Auditor-General's Report 1996, Sydney.

Mellor, T. (1996), 'Why Governments Should Produce Balance Sheets', Australian Journal of Public Administration 55(1): 78-81.

National Commission of Audit (1996), Report to the Commonwealth Govennment, AGPS, Canberra (June).

Redburn, F. (1993), 'How Should the Government Measure Spending? The Uses of Accrual Accounting', Public Administration Review 53(3): 228-36.

Robinson, M. (1996), Public Sector Net Worth: Is It Worth Measuring?, Commonwealth Parliamentary Research Service, Canberra.

Scott, G. (1995), 'New Zealand's Fiscal Responsibility Act', Agenda 2(1): 3-16.

Suits, D. \& R. Fisher (1985), 'A Balanced Budget Constitutional Amendment: Economic Complexities and Uncertainties', National Tax Journal, December: 467-78.

Treasury (1995), 'Submission', in Joint Committee of Public Accounts, Reference: Inquiry into Fiscal Responsibility Legislation and Whole of Government Reporting for the Conmonwealth, Submissions, Volume 1, Canberra.

von Hagen, J. (1991), 'A Note on the Empirical Effectiveness of Formal Fiscal Restraints', Journal of Public Economics 44: 199-210.

Walker, R. (1995), 'Submission', in Joint Committee of Public Accounts, Reference: Inquiry into Fiscal Responsibility Legislation and Whole of Government Reporting for the Commonwealth, Submissions, Volume 1, Canberra.

Williamson, O. (1985), The Economic Institutions of Capitalism: Firms, Markets, Relational Contracting, The Free Press, New York. 